\title{
A FILÓSOFA NO DIVÃ DA SEMIÓLOGA: JULIA KRISTEVA, LEITORA DE SIMONE DE BEAUVOIR
}

\author{
Resenha do livro Beauvoir presente, de Julia Kristeva \\ Tradução de Edgard de Assis Carvalho e Mariza Perassi Bosco. São Paulo: Edições Sesc, 2019.
}

NEVES, Angela das ${ }^{1}$

Em comemoração aos setenta anos daquele que pode ser considerado o livro fundador do feminismo, O segundo sexo (1949), de Simone de Beauvoir (1908-86), esta leitura crítica e profunda da semióloga búlgaro-francesa Julia Kristeva (1941-) presta uma homenagem a uma das maiores escritoras francesas de sua geração. Tendo atravessado o século XX e o novo milênio, o tratado de Beauvoir sobre a liberdade da mulher permanece como o grande clássico sobre o assunto. Este livro de Kristeva é um convite a revisitá-lo.

Dos nove textos de Kristeva coligidos no volume, a maioria consiste em conferências proferidas (desde 2003) e depois republicadas em livros, e estuda, de forma concisa e abrangente, a obra existencialista da escritora francesa, que estreou como romancista na década de 1940. Assim como a edição francesa (Beauvoir présente, Librairie Arthème Fayard, 2016), de que esta coletânea é tradução, recebeu o título do ensaio principal do volume. Além de uma entrevista da semióloga para uma edição especial do Le Monde, os outros documentos menores, também aqui contidos, apresentam as laureadas com o Prêmio Simone de Beauvoir, idealizado por Julia Kristeva no centenário da filósofa, que desde 2008 é concedido a pessoas notáveis por sua atuação em prol da liberdade feminina no mundo.

Tendo constituído uma carreira de intelectual e escritora consistente, por meio da qual conviveu com os principais pensadores e escritores de seu tempo, pode-se afirmar, com o respaldo uníssono de Kristeva, que Simone de Beauvoir construiu um pensamento filosófico e uma obra coerentes com seu modo de existência. Desde suas escolhas pessoais e íntimas, até suas ocupações profissionais e literárias, refletem suas formas de ver o mundo, as quais foram

\footnotetext{
${ }^{1}$ Pós-doutoranda em Literatura Brasileira pelo Instituto de Estudos Brasileiros da Universidade de São Paulo (IEBUSP). Doutora em Estudos Linguísticos, Literários e Tradutológicos em Francês pela Faculdade de Filosofia, Letras e Ciências Humanas da Universidade de São Paulo (FFLCH-USP). E-mail: angela.neves@usp.br.
} 


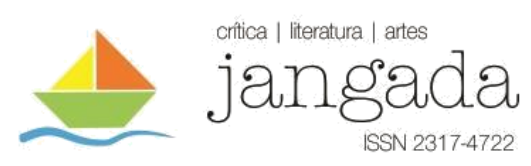

transportadas de maneira sensível para sua obra de ficção e não ficcional. Trata-se de uma coincidência rara e feliz entre o que se faz e o que se prega. Desse modo, justifica-se a análise biobibliográfica que Kristeva empreende neste livro, passando com destreza do comentário biográfico ao crítico e analítico sobre o conjunto de seus textos.

De professora a ensaísta e escritora, assim como Beauvoir, envolvida por relacionamento afetivo e intelectual com os maiores estudiosos de sua geração, Kristeva perfaz uma trajetória profissional em que a mulher se sustenta de modo independente e genial entre seus pares (em grande parte, do sexo masculino). ${ }^{2}$ São intelectuais engajadas da forma mais esperada, porém a menos usual, no que se refere à passagem da teoria à prática. Simone de Beauvoir associou suas reflexões sobre os papéis da mulher na sociedade à postura política de esquerda, num momento em que, para assumir essas duas escolhas, era preciso ocupar (às vezes por meio da força intelectual) um lugar de fala específico.

A opção por gêneros literários híbridos da autoficção (memórias, autobiografia) e sua exímia prática da epistolografia; a realização de viagens pelo mundo todo e o desejo de expandir o alcance de seu pensamento, consequentemente, de sua comunicação com grandes escritores; a prática literária e ensaística, que não se deteve apenas no formato do livro, mas nas demais mídias de seu tempo (revista, jornal, rádio, conferências), tudo isso revela o que Kristeva chama de a "pulsão verbal" (p. 39, 81) de Simone de Beauvoir na construção pessoal como mulher livre. Traduzida para diversos idiomas, quando ainda escrevia seus livros, Beauvoir nasceu e se tornou mulher, desfazendo mitos, e quebrando todos os paradigmas sociais (como os deveres femininos do casamento, da maternidade, da heterossexualidade), provocando o que Kristeva denominou "uma revolução antropológica sem precedentes" (p. 13). A igualdade de sexos e a universalidade de direitos são princípios do feminismo fundado por Beauvoir e que permanecem até hoje. Sua atuação e sua repercussão na defesa dos direitos da mulher é tamanha que, após décadas, sua fala é ainda moderna e polêmica.

Nesse sentido, Beauvoir está onipresente. Seu nome veste todo pensamento feminino de um traje particular. Não somente $O$ segundo sexo, atualmente relido ao modo de cada linhagem feminista (p. 62), mas seus romances e a própria imagem de Beauvoir (mulher e obra) permanecem em discussão. Essa presença se perfaz num caminho louvável, em que o discurso

\footnotetext{
${ }^{2}$ Simone de Beauvoir fez parte do grupo de filósofos existencialistas fundadores da revista Temps Modernes, nos anos 1940, e conviveu com Jean-Paul Sartre até o final da vida dele. Julia Kristeva está entre estudiosos do estruturalismo os idealizadores da Tel Quel, nos anos 1970, sendo casada com Philippe Sollers.
} 


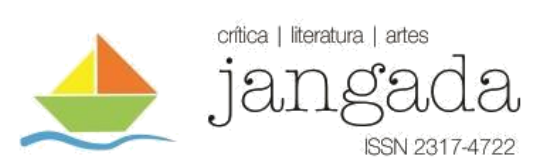

se realiza por meio de uma ação militante. Para Kristeva, há um "gênero do romance beauvoiriano", que "é identificado na interseção entre o íntimo e o político" (p. 35).

Conforme bem define Julia Kristeva, Beauvoir “disse e demonstrou que é possível a uma mulher ser livre" (p. 62). Assim, o exemplo pessoal dela reforça sua teoria e torna-se um modelo de conquista político-social para todas. Nesse caminho beauvoiriano reside também a raiz de sua teoria: o universal é alcançado por meio da experiência individual: “[...] antes de se transformar em um projeto político, ao mesmo tempo que se tornava um, ao escrevê-lo, libertou sua experiência interior, incluindo seus sonhos e seus desejos” (p. 76).

Por sua vez, enquanto a psicanalista Kristeva debruça-se sobre a filósofa para analisar seus sonhos, a partir da leitura de textos autoficcionais (p. 63-76) ou a raiz psicanalítica de $O$ segundo sexo (o conceito de que "o sexo é o corpo vivido pelo sujeito" p. 64 e 78); o interesse da semióloga está em avaliar a pulsão de Beauvoir como escritora ("captar o excesso de pulsão na linguagem sempre foi um antidepressivo na cultura do verbo", p. 81), que considerava essa como a principal ocupação de sua vida. Ainda na Bulgária, Kristeva afirma que entrou em contato com $O$ segundo sexo por volta de 1958 (aos dezessete anos), e nunca mais parou de ler Beauvoir. Em diversos momentos deste livro, ela assume sua "dívida com Simone de Beauvoir" (p. 23, 49, 91). Seus ensaios (por exemplo, O gênio feminino, de 1999) e sua ficção (Os samurais, de 1990) refletem essa leitura, bem como a sua atuação social, de que é exemplo a criação do Prêmio Simone de Beauvoir, na França.

Neste ano de comemoração dos setenta anos de $O$ segundo sexo, numa edição em que o objetivo é falar de "coisas de mulher", concluímos que esses postulados que herdamos da sociedade patriarcal em que crescemos são facilmente desarmados por meio do reconhecimento da atuação de mulheres como Simone de Beauvoir e Julia Kristeva. Tanto "coisa de mulher" como "segundo sexo" são expressões que, se sob um primeiro olhar procuram codificar sem definir, restringindo e limitando, por meio de uma análise mais profunda, numa releitura crítica, ressignificam estereótipos, ilustrando o desejo e a atuação concreta da mulher na sociedade, reconhecendo-se assim o seu legado.

Se "o segundo sexo é livre", como bem demonstrou Simone de Beauvoir, "coisa de mulher" é alta cultura, criativa e independente, feita de forma consciente, lúcida e revoltada contra as injustiças sociais. Vistas desse modo, essas expressões contrapõem diretamente mulher e homem não para promover uma guerra dos sexos, mas sim para, de fato, igualá-los em termos humanos e distingui-los no que os fraterniza. Afinal, nas palavras de Simone de Beauvoir citadas por Kristeva na última página de seu ensaio final (p. 119): “em ambos os sexos 
se representa o mesmo drama do corpo e da mente, da finitude e da transcendência; ambos são corroídos pelo tempo, vigiados pela morte, têm a mesma necessidade essencial do outro; e podem tirar de sua liberdade a mesma glória” (Le Deuxième sexe, Paris: Gallimard, 1949, v. II, p. 573).

\section{REFERÊNCIAS BIBLIOGRÁFICAS}

BEAUVOIR, Simone de. Le Deuxième sexe. Paris: Gallimard, 1949. 2 v.

KRISTEVA, Julia. Beauvoir presente. Trad. Edgard de Assis Carvalho e Mariza Perassi Bosco. São Paulo: Edições Sesc, 2019. 